\title{
EL ESPEJO DEL OLVIDO: LA IDEA DE AMERICA EN LAS MEMORIAS DE JUAN BAUTISTA TUPAC AMARU
}

\author{
POR \\ HERNAN NEIRA \\ Ecole des Hautes-Etudes en Sciences Sociales. Paris
}

«A los 80 años de edad, y después de 40 de prisión por la causa de la independencia, me hallo transportado de los abismos de la servidumbre á la atmósfera de la libertad, y por un nuevo aliento que me inspira, animado á mostrarme a esta generación, como una víctima del despotismo que ha sobrevivido á sus golpes, para asombro de la humanidad, y para poderle revelar el secreto de mi existencia como un esquisito y feroz artificio que se transmitian los tiranos para tener el placer de amargarla» (1). Así comienza Juan Bautista Tupac Amaru un escrito conocido como sus Memorias, texto ventrílocuo, si hay alguno en la historiografía americana. Ventrílocuo, porque constantemente habla con multiplicidad de voces. Con una es el inca orgulloso y rebelde que reivindica el señorío de su raza en el Perú; con la otra, un indio adolorido y menesteroso que para hablar de sí asume la voz del liberal cuya filosofía le condena. Es que la historia de Juan Bautista está marcada con el signo del olvido. Olvido de un inca que, ya sin fuerzas, ha dejado de buscar o ya no encuentra sus raíces tras cuarenta años de exilio en España; olvido de bibliotecarios y conservadores que han perdido el manuscrito y obligan, hoy, a referirse a versiones impresas; olvido, en fin, de los historiadores, más atentos a otros miembros de su familia, ignorando

(1) Tupamaru, El dilatado cautiverio, bajo del gobierno español, de Juan Bautista Tupamuru, $5^{8}$ nieto del último emperador del Perú, Buenos Aires. Imprenta de los Espósitos, 1826, pág. 1. Salvo indicación contraria, todas las referencias son extraidas de dicha edición. Fue publicado posteriormente en: Buenos Aires, Diario La Nación, 23/3/1930; Los Pequeños Grandes Libros de la Historia Americana, Lima, 1941; y, Fondo de Cultura Popular, Lima, 1964. De manera genérica, designamos el texto, en cualquiera de sus ediciones, bajo el nombre de Memorias. 
que, entre todos, es quizás Juan Bautista Tupac Amaru quien mejor puede mostrarnos lo sucedido, no en los campos de batalla, sino en la mente de los guerreros y del pueblo vencido. ¿Quién es, pues, este hombre que reclama cartas de nobleza indígena y que nunca le fueron concedidas?, ¿cuál el origen del manuscrito?, ¿cómo y con qué criterios se representa él mismo la historia de la Conquista y el lugar de los Tupac Amaru en ella?, ¿se trata acaso de una "visión de los vencidos»?

\section{1. ¿Quién es Juan Bautista Tupac Amaru?}

Juan Bautista Tupac Amaru es medio hermano de José Gabriel Tupac Amaru, líder indígena que se levantara en Cuzco, en noviembre de 1780, contra el gobierno español. La sublevación fue derrotada y José Gabriel preso, torturado y descuartizado en mayo de 1781 junto a varios miembros de su familia. Se extiende entonces una violenta represión que alcanza a la mayoría de sus parientes y amigos. Poco después caía preso Juan Bautista Tupac Amaru, autor de las Memorias que aquí estudiamos, y su casa saqueada, "todo por mis paisanos, amigos y beneficiados» (2). Sigue un juicio en el que Juan Bautista, probablemente para quedar libre de cargos, niega pertenecer a la familia Tupac Amaru y haber participado en el levantamiento. Entonces afirma que su padre y el del líder rebelde son dos hombres distintos, pues su madre habría estado unida a otro indio previamente. Ese argumento de Juan Bautista justifica los vínculos de amistad y su cercanía a los rebeldes, pero niega el lazo de sangre entre él y la célebre familia peruana (3). Rechazar el vínculo sanguíneo era esencial si se toma en cuenta que la corona española deseaba destruir a toda la familia Tupac Amaru, de modo que ninguno de sus miembros pudiera arrogarse una soberanía sobre el Perú en detrimento de la hispánica.

Juan Bautista no purgaría su pena, al menos inmediatamente. En enero de 1782, en virtud de un Pacto de Paz firmado entre los indios y las autoridades españolas, él y otros presos quedan libres, aunque la libertad no hace fácil la vida cotidiana. Subsiste un clima de desconfianza, de tensión y de acoso, pues se teme

(2) Tupamaru, [1], pág. 7.

(3) Ver auto del 23/5/1781 contra Juan Bautista. 
que la influencia, jamás extinguida, de los Tupac Amaru, se traduzca en un nuevo brote de rebeldía. Las autoridades españolas recelan e investigan sus movimientos, hasta el momento en que el Virrey Jáuregui rompe el Pacto de Paz y decide detenerlos (4). La suerte de los indios quedó echada cuando el ministro Gálves escribe a Jorge Escobedo, desde San Ildefolso, el 6/9/1783:

los principales traidores y Reveldes de esta conspiración deben sufrir ahí [en Perú] la pena capital a que les condenan sus delitos, y que los demás que no la merezcan deben remitirse a España con la causa en segura custodia, para que no queden en ese Reyno restos ninguno de la infame y vil familia de los fingidos Tupac-Amaros ... procurando se aprehendan todos los individuos que no se hayan podido coger de dicha familia y especialmente a Juan [Bautista], hermano de Diego (5).

Juan Bautista es preso y parte, junto a los familiares y amigos que no han sido ejecutados, a un destierro indefinido en cuyo trayecto perecen dieciocho de los veintinueve desgraciados. Al llegar a España, la familia Tupac Amaru se encuentra muy reducida; muy pronto ninguno de ellos quedaría vivo, excepto Juan Bautista, quien, tras algunos meses en los castillos de San Sebas-

(4) El 5 de mayo de 1783, el Virrey informa en un oficio a Gálvez, ministro de Carlos III: "He vivido receloso y poco satisfecho de las of ertas que hicieron los rebeldes, cuando advirtieron el indulto general que les concedi, y siempre he creído que había de ser indispensable para afianzar la tranquilidad pública el extraer y sacar del Reino a los cabezas y principales caudillos de aquéllos [...]. Suponiendo con sagacidad y sigilo que algunas personas condecoradas de quien ellos habian hecho al parecer mayor confianza las aconsejasen y persuadiesen a que los solicitasen por sí, y que para ellos se me presentasen en esta ciudad [Lima], haciéndoles creer que por este medio podían conseguir mayores ventajas. Esta diligencia no fue del todo inútil, pues por ella logré que el día 4 de enero [de 1783] próxime se me presentasen personalmente Mariano Tupac Amaro, hijo mayor del rebelde José Gabriel [...] y otros cinco indios [...]. Igual encargo tenía hecho [...] al Coronel Don Gabriel de Avilés [...] y a otras personas de confianza, por cuyos avisos he tenido individual noticia de cuanto han ejecutado en este tiempo Diego Tupac Amaro y sus sobrinos. Y aunque hasta ahora no habían dado unas pruebas positivas y claras de su reincidencia, todos convenían en que era sospechosa y poco segura su fidelidad" (el Virrey Jáuregui a José Gálves, Lima 5/5/1783). Pero incluso dentro de la legislación de Indias, la corona encuentra dificultades para constituir un delito que se les pueda imputar. Benito de la Mata, encargado por el Virrey del sumario, lamenta que los únicos motivos para arrestar a 133 sospechosos sean "una voz vaga o porque en la rebelión [de 1780] se distinguieron sin que se sepa hayan dado posteriormente causa nueva [...] pues aún en là formación de la causa principal de Diego [Tupac Amaru] y demás de su familia no puedo fijar pie en cosa sustancial" (Benito de la Mata al Virrey Jáuregui, Cuzco, 29/5/1783).

(5) El ministro Gálvez a Jorge Escobedo, San Ildefonso, 6/9/1783. 
tián y de Santa Catalina, es confinado en Ceuta en 1788. Probablemente Juan Bautista también hubiera muerto en Africa, viejo y solo, olvidado del mundo, si a partir de 1813 el agustino Marcos Durán Martel, que acababa de participar en la sublevación de Huánuco, no hubiera sido desterrado también a Ceuta. Nada más saber quién era su compañero de infortunio, Marcos Durán le acompañó y ayudó, particularmente a cultivar un huerto del que extraían los medios para subsistir. Del mismo modo, el agustino realizó los trámites para hacer efectiva la liberación de Juan Bautista cuando las Cortes indultaron a todos los presos políticos americanos. En septiembre de 1822, tras cuarenta años de presidio, con 84 años de edad, Juan Bautista Tupamaru desembarca en Buenos Aires.

Allí es recibido y alojado por Juan Azopardo, que también había sido compañero de presidio en Ceuta y héroe de las primeras campañas navales argentinas. Apesadumbrado y sabiéndose débil, incapaz, por la edad, de trabajar, sólo le queda a Juan Bautista hallar los medios para sobrevivir. Entonces, con el probable patrocinio de Azopardo, eleva al gobierno bonaerense una solicitud en virtud de un lejano levantamiento y de un apellido que algunos detractores quisieron, también en Argentina, aunque infructuosamente, negarle. El gobierno, por medio del ministro Bernardino Rivadavia, le escucha y concede, en octubre de 1822, una ayuda de 30 pesos mensuales a condición de que el inca escribiese, de su puño y letra, la historia de sus padecimientos, sus Memorias.

¿Por qué el interés gubernamental en un anciano indígena? No había sido, Juan Bautista, ni jefe ni estratega. Según sentencia del juez Areche, dictada en Cuzco el 14/7/1781, las autoridades españolas nunca pudieron probarle ser más que colaborador y cómplice de su medio hermano José Gabriel, «acompañándole, ayudando a cargar la Artillería, y caminando con armas, reconociéndole de la familia» (6). Pero cuarenta años después del juicio en que negaría todo parentesco con los líderes indígenas, nada más pisar América, y probablemente antes, Juan Bautista, reclama ser el $" 5^{\circ}$ nieto del último emperador del Perú». En las Memorias, retomando la tradición, se declara, como todos los Tupac Amaru, heredero directo de Huayna Capac. Puesto que al desembarcar en Buenos Aires todos los demás miembros de la familia rebelde han muerto ejecutados o en el exilio, Juan Bautista se confirma legítimo y único descendiente de los emperadores peruanos. La

(6) Sentencia del juez Areche, Cuzco, 14/juliø/1781. 
tesis le favorece demasiado directamente en la polémica contra quienes le consideraban impostor, pero resulta coherente si se considera que, al escribir, Juan Bautista ya no corre los riesgos que corría en Cuzco (7). El árbol genealógico de Juan Bautista sería entonces el siguiente:

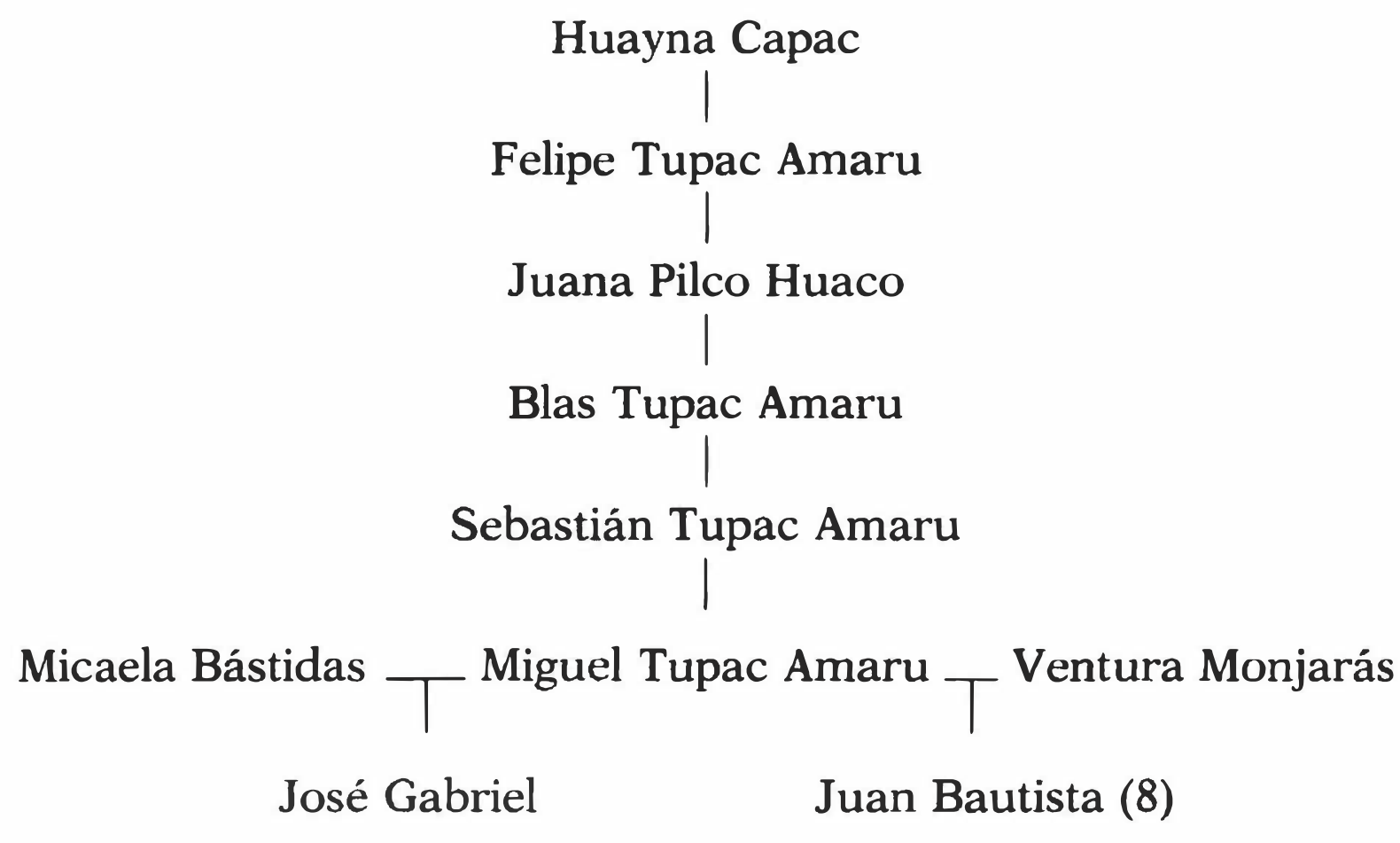

Tal hecho no podía pasar desapercibido a ciertos próceres argentinos. Pocos años antes, en el Congreso de Tucumán de 1816, Belgrano y otros, al tiempo de declarar la independencia, proponen una restauración incaica. Según Mitre, los participantes en el Congreso de Tucumán

«tenían un propósito común, y era trasladar la sede del Gobierno al interior del Perú y restablecer, si era posible, la antigua monarquía de los Incas» (9)

(7) Perú, hoy, se sostiene en muchos libros de texto, la posición de Juan Bautista. En efecto, "oficialmente", Juan Bautista es medio hermano del máximo lider de la independencia nacional, pues para aquella nación andina, los máximos héroes no son San Martín y O'Higgins, generales argentino y chileno respectivamente que encabezarían el ejército libertador, sino los Tupac Amaru. Perú no podría aceptar como suyo un héroe nacional chileno.

(8) Juan Bautista Tupac Amaru, Cuarenta años de Cautiverio, Los Pequeños Grandes Libros de la Historia Americana, Lima, 1941, pág. 76.

(9) Bartolomé Mitre, Historia de Belgrano y de la Independencia Argentina; citado por F. A. Loayza en Tupac Amaru, [8], pág. 68. 
Por eso, cuando Belgrano se presentó en Tucumán, observó que el Congreso era monarquista y que

"podía contar en su seno con una gran mayoría, en favor de sus ideas políticas, especialmente entre los diputados de Alto Perú, afectos a su persona y partidarios de la Dinastía de los Incas [.... y] declaró que en su concepto la forma de gobierno más conveniente para estas provincias sería la de una monarquía temperada, llamando la Dinastía de los Incas, por la justicia que en sí envuelve la restitución de esta Casa, tan inocuamente despojada del trono" (10).

Entonces se designó la candidatura en los Tupac Amaru, pero Juan Bautista estaba en presidio y otras circunstancias políticas impidieron que el proyecto prosperara, reduciéndolo a proclamar "la sombra de una sombra». Cuando el indio vuelve es tan tarde para él como para sus pretensiones dinásticas. Anciano e inexperto políticamente, ha permanecido al margen de los asuntos americanos, donde las tendencias monárquicas de algunos patriotas han sido superadas por las republicanas de San Martín y O'Higgins, que liberarían el Perú. Juan Bautista en Buenos Aires es un hombre disminuido en sus fuerzas morales y físicas; careciendo de toda posibilidad de recuperar el sitial que pocos años antes le habían ofrecido los patriotas, sólo le queda esperar a morir mientras redacta sus Memorias.

\section{CONTENIDO DEL TEXTO}

Las Memorias constituyen un texto raro y, por desgracia, estudiado casi exclusivamente bajo la óptica "patriótica», en la que se busca más la confirmación de las creencias fundadoras de una república o de la tradición indigenista peruana que el conocimiento histórico. Es el complemento indispensable de los documentos sobre las sublevaciones peruanas conservados en el

(10) Ibidem, págs. 68 y 70. 
Archivo de Indias (11). Aunque no gozan de su precisión, son exactos en la medida que muestran la visión de mundo y el proyecto indigenista ventrílocuo de un Tupac Amaru. Juan Bautista nos entrega el relato de sus sufrimientos mostrando la manera como la historia afecta a un pueblo a través de la destrucción moral y física de una familia célebre, así como la amargura de un hombre que, desterrado, jamás volverá a ver ni a los suyos ni a su patria. Su aporte reside en su capacidad de sintetizar, dar coherencia y ligar en la unidad del pensamiento y la vida de un hombre una serie de hechos dispersos de los cuales generalmente sólo se estudian informes oficiales, pasando por alto su repercusión y la forma como un hombre, el sujeto de dichos documentos, los interpreta: ¿cómo afectó la represión a un miembro cualquiera de la familia Tupac Amaru?, ¿alteró o traicionó el prolongado destierro el proyecto indigenista de Juan Bautista?, ¿determinó la revuelta una nueva forma de interpretar la historia americana?

Desde el punto de los hechos, las Memorias relatan la detención, el proceso al que fue sometido Juan Bautista a partir de la derrota del movimiento encabezado por su medio hermano José

(11) Olvido del olvido, tal es la divisa de Juan Bautista y de cuanto le concierne. Todo parece indicar que el manuscrito de las Memorias existe. ¿Dónde? No en la Biblioteca Nacional del Perú, como sería de esperar, pues "el documento original se encuentra en la Biblioteca Nacional argentina en Buenos Aires", documento del cual "lamentablemente nuestra institución no tiene copia" (Irma García, de la Biblioteca Nacional del Perú a este autor, 10/6/89). Consultado epistolarmente, Buenos Aires tardaría meses en responder que "absolutamente todos los manuscritos que poseía esta Biblioteca pasaron hace más de veinte años al Archivo General de la Nación", y que "lo único que tenemos es un folleto impreso en la Imprenta de los Espósitos, 1822, titulado El Dilatado Cautiverio bajo el gobierno español, de Juan Bautista Tupamaro, $5^{\circ}$ nieto del último emperador del Perú, 38 págs. Buenos Ayres" (Julio Oscar Zolezzi, de la Biblioteca Nacional Argentina, a este autor, 20/12/90). La intervención directa en Archivo General de algunos colaboradores de este autor no permitió encontrar el manuscrito, pues los conservadores de dicha institución ignoran dónde y bajo qué rúbrica buscarlo.

A falta del original, era indispensable trabajar la edición más cercana al manuscrito, razón por la cual escogimos la Imprenta de los Espósitos, que fue microfilmada. En cuanto a la posteriores, todas parecen copiarla, actualizando únicamente la puntuación, del mismo modo que la edición peruana de 1964 copia, palabra por palabra, aquella aparecida en Lima en 1941, con notas de Francisco A. Luayza. Las Memorias vieron la luz por segunda vez en las páginas del diario La Nación, en el suplemento dominical del 23 de marzo de 1930. Desgraciadamente, dicho suplemento ha desaparecido (sic) de la Biblioteca Nacional en Buenos Aires. ¿El o los manuscritos? Lo único que nos sea posible afirmar es que existió al menos un manuscrito de las Memorias, que debe encontrarse en médio de algún anaquel aciago, en la biblioteca bonaerense que conserve el justificativo a cambio del cual Bernardino Rivadavia decretó la pensión en favor de Juan Bautista. Quizás allí, un día, alguien lo encuentre por azar. 
Gabriel, insistiendo en los lazos de parentesco entre ambos, así como el presidio que hubo de sufrir el primero en Ceuta y su posterior regreso a Buenos Aires. La mayoría de los sucesos han sido confirmados por documentos españoles y, en lo que concierne a la discusión sobre la posibilidad de tratarse de un relato apócrifo, hoy resulta escasamente probable. En la peor de las hipótesis, quienquiera lo haya escrito, tuvo que haber formado parte de la caravana de desgraciados que salió en condiciones miserables desde Lima, es decir, aunque no haya sido Juan Bautista, fue un Tupac Amaru, un pariente cercano o un insurgente muy próximo a éstos.

Se dirá, tal vez, que es un escrito de circunstancias en el que Juan Bautista se juega una pensión, y que por ese motivo se ve obligado a escribir a gusto de sus benefactores. Sin duda es cierto, pero de ningún modo se trata de un texto de complacencia, pues proporcionalmente hay pocas loas al gobierno bonaerense. El tono del escrito no es el del panegírico, sino el de la queja y la amargura. Lo extraño, sin embargo, es que las Memorias superan en mucho lo que se podría esperar de un escrito originado así, superación que no proviene de su calidad literaria, que no la tiene, sino del esfuerzo, tan insistente como estéril por dar a América una identidad indígena que Juan Bautista, el último de los Tupac Amaru, $5^{\circ}$ nieto del emperador inca, héroe de la independencia peruana, ya no sabe cómo concebir. Pero entonces, ¿bajo qué marco conceptual y qué piensa Juan Bautista cuando piensa América o su historia?

\section{HiJO ILEGÍTIMO DE LAS LUCES}

Aunque la avanzada edad pueda justificar gran parte del olvido (12), ello no basta para explicar algunos párrafos de sus Memorias. Por ese motivo es indispensable plantear la hipótesis de que el aprendizaje de la lengua española jugó, probablemente, un rol esencial en la transformación de Juan Bautista. Es en Ceuta donde se encuentra, por primera vez, en medio del mundo hispánico, pues hasta entonces su comunidad de vida había sido esencialmente indígena. Desterrado, pero con libertad de movimientos en el recinto urbano, debe, para ganarse el pan, tratar

(12) Tupamaru [1], pág. 2. 
con hispanoparlantes (13). Juan Bautista, ante las circunstancias, termina familiarizándose con ese nuevo mundo que, sin embargo, siempre le será hostil:

Ignoraba el idioma español [...] y las costumbres de esta nación; para satisfacer mis necesidades me era preciso el comercio con los demás [...] Mas nunca sentí tanto la atmósfera que respiraba como cuando todos mis connatos para tomar una educación [...] excitaban el escarnio y la pifia solamente (14).

El idioma español le permitirá tratar con los patriotas americanos que llegarán al mismo sitio de destierro y, posteriormente, escribir o dictar las Memorias. Junto a la adquisición del nuevo idioma, Juan Bautista adquiere las ideas de las cuales aquél es portador; alejado de la comunidad de origen, probablemente debió optar entre permanecer en silencio o, sin darse cuenta, establecer una comunidad lingüística e ideológica con los patriotas que habría de encontrar (15). Con todo, resulta admirable, al leer las Memorias, su semejanza retórica con ciertos escritos del Siglo de las Luces, donde la historia es vista como fruto del progreso de la razón, tal cual Juan Bautista la ve:

ciertamente todo me era aflictivo [durante el destierro], y entonces las afecciones de la realidad me conducían irresistiblemente á la desesperación, mientras que ahora [en Buenos Aires] los recuerdos [del cautiverio] son acompañados de positivos consuelos, y al fin de la triste carrera veo infalible el reinado de la razón; [veo] que el espíritu humano marcha iluminado contra los tronos; que el genio amenaza al despotismo con la muerte, y que existe al Norte de nuestro emisferio una nación que habiendo sido esclava como la mía rompió sus cadenas para realizar instituciones que aplaude el filósofo y que hacen la emulación del Sud por imitar su verdadera gloria (16).

(13) Tupamaru [1], pág. 60.

(14) Ibidem.

(15) Juan Bautista también aprendería a escribir. En uno de los autos incoados en su contra, el actuario agrega que el inca "no firmó por no saber [firmar]" $(23 / 6 / 1781)$. F. A. Loayza se opone a dicha tesis en los siguientes términos: "no es creible el analfabetismo de Juan Bautista Tupac Amaru. Sin saber leer ni escribir, no habría podido desempeñar los cargos de responsabilidad y confianza al lado de su hermano José Gabriel Tupac Amaru", Juan Bautista Tupac Amaru, Las Memorias de Tupac Amaru, Lima, Fondo de Cultura Popular, 1964, pág. 71. Pero en realidad, los cargos ocupados por Juan Bautista no parecen haber sido de primera importancia, pues de lo contrario se le hubiera ejecutado. Por lo demás, para colaborar en una revolución, entonces, no siempre se necesitaba saber leer.

(16) Tupamaru [1], pág. 7. 
Poco después continúa con una frase que hace pensar muy particularmente en la primera Declaración de Derechos del Hombre:

La naturaleza, me decía á mí mismo, nos impele ácia [sic] la libertad, y la experiencia de los siglos solo nos mostrará al hombre esclavo. ¡Sus derechos estando escritos en su corazón, en la historia sólo estará su humillación! (17).

En efecto, la argumentación tiende a probar que, por mucho que los indios se encuentren de facto esclavizados, desde el punto de vista jurídico conservan todos los derechos que se desprenden de su naturaleza, concebida como una sustancia inmutable. En el fondo de dicha argumentación se encuentra la tesis de inalienabilidad de los derechos del hombre, que forman parte de su propia esencia, de tal modo que ninguna situación de facto, ni siquiera la conveniencia de quien se somete a ella, podrá justificar la esclavitud (18).

Juan Bautista considera la historia de América desde una idea naturalista del hombre. La llegada de los españoles aparece como el momento inicial de la degeneración y, la Independencia, como el instante a partir del cual la degeneración se detiene y se convierte en posibilidad de retorno a un estado de bienestar originario. Ahora, hablar de retroceso o avance supone haber caracterizado las referencias de base para medir el movimiento. La referencia de Juan Bautista es temporal, pero no es propiamente histórica, pues no concibe que la naturaleza humana evolucione por sí misma en el tiempo, sino únicamente a raíz de una catástrofe extraña. Esta catástrofe, para los pueblos indígenas, sería la Conquista. Así, Juan Bautista comparte la visión de ciertos pensadores europeos, entre los cuales hay que incluir a Las Casas y a Rousseau, según la cual, si los indios manifiestan caracteres de violencia o de odio se debe al "contagio" de las costumbres españolas pues los naturales de América son «naturalmente humanos y dulces" (19) y hubieran gozado siempre de tales cualidades de no haber tenido contacto con la "civilización».

La dulzura define y fija la substancia del indio más allá de circunstancias empíricas y de estados de hostilidad en que pueda

(17) Ibidem, pág. 6.

(18) Rousseau, Discurso Sobre los Fundamentos de la Desigualdad Entre los Hombres y El Contrato Social.

(19) Tupamaru, [1], pág. 8. 
verse involucrado. Por eso, la bondad natural indígena es para Juan Bautista el principio de comprensión de las palabras "aquí no hay más cómplice que tu y yo; tu por opresor, y yo, por libertador, merecemos la muerte» (20) que su hermano José Gabriel dirigiera al juez que le condenaría:

el precio de esta contestación la sentirán las almas que saben odiar cuanto es devido á los déspotas; ella es una verdad conocida de los filósofos, porque saben bien que en un país despotizado sólo el déspota es criminal; que el hombre esclavizado se halla en un estado contra la naturaleza, y que el tirano ha hecho degenerar á ésta en su daño (21).

Pero Juan Bautista pasa por alto, voluntaria o involuntariamente, que los incas también fueron un pueblo conquistador $y$ que deben su renombre al sometimiento de las naciones vecinas, hecho que les situaba lejos de la bondad natural. El inca desconoce el contenido exacto de las guerras indígenas, no porque en su familia no haya oído hablar de ellas, sino porque esa tradición oral se ve, probablemente, contaminada por la visión eurocentrista de la Conquista. En él habla la concepción que la Europa de las Luces tenía de la historia precolombina, basada en esquemas imaginarios destinados a contraponer una imagen ideal de la sociedad a los inconvenientes del Antiguo Régimen.

Es lógico entonces que el inca vea en el destierro no sólo un crimen contra los pueblos indígenas, sino un «atentado contra la humanidad" (22), pues Juan Bautista comparte, al menos en Buenos Aires, la idea cara a los patriotas de que existe una sola especie humana. Sin embargo, el universalismo de Juan Bautista no le impide esbozar una concepción nacional que supera los marcos raciales. Contrapone así, tanto a la España de la Conquista como a la España liberalizante de principios del XIX, una cierta idea de nación donde las fronteras, ora continentales, ora limitadas a cada república, no están aún suficientemente definidas. Sin embargo, Juan Bautista, cuanto más acérrimo es en su discurso anti-español y anti-europeo, más se traiciona y más utiliza la conceptualización eurocentrista para comprender las relaciones entre el Viejo Mundo y el Nuevo.

Aparte de hijo ilegítimo y ecléctico de la ilustración, Juan

(20) Ibidem, pág. 4.

(21) Ibidem.

(22) Ibidem, pág. 37. 
Bautișta era también cristiano y probablemente partidario de la monarquía antes que de la república, hecho comprensible tomando en cuenta que los Tupac Amaru se consideraban la única autoridad legítima del Perú, y que dicha exigencia se fundamenta en una concepción hereditaria del poder. Entre los objetos confiscados en su primera captura, en 1781, figuran dos pequeños lienzos. El primero representa una virgen del Carmen, testimonio de la religiosidad del inca, muy distinta de la que fuera antiguamente la de su pueblo; el segundo, un escudo del Rey de España, que, según F. A. Loayza, podría haber sido conservado por Juan Bautista como modelo para diseñar el suyo posteriormente, en la esperanza de que la rebelión triunfara (23).

El inca acusa a España de haber privado a la humanidad de la "ciencia social» y "natural» indígenas para substituirlas por el despotismo y la oscuridad (24). Sin duda es cierto, tan cierto que el propio Juan Bautista ya no puede exponer la ciencia social de su pueblo más allá de un esquema supersimplificado. Todo el saber historico-político sobre la vida social de sus ancestros se limita, al menos en las Memorias, a la estructura que dividía a su pueblo en grupos de diez familias bajo la autoridad de un jefe que, reunido a otro diez, se sometía a la jurisdicción de un tercero, y así hasta llegar al emperador (25). Lo mismo sucede con respecto a la ciencia natural; para justificar su tesis, Juan Bautista agrega una nota donde dice que «Bernardo Díaz [Bernal Díaz del Castillo ¿?] que acompañó á Cortés, Herrera, Solís refieren que en América había jardines donde se cultivaban plantas medicinales para la utilidad pública» y que "el primer jardín de Europa fue el de Padua formado por un decreto de la República de Venecia el 30 de junio de 1545" (26). Prácticamente la única, y vaga, referencia hecha por Juan Bautista a la historia antigua americana proviene entonces de "Bernardo Díaz», español, mientras que le sobra precisión para hablar del Viejo Mundo:

El género humano respeta á Catón y se humilla bajo del yugo de Cesar. La posterioridad honra la virtud de Bruto, pero no la permite sino en la historia antigua. Cortés y Pizarro someten una nación virtuosa, feliz y rica, asesinando á sus reyes,

(23) Los lienzos son reproducidos en Juan Bautista Tupac Amaru [8], págs. 97-99.

(24) Tupamaru [1], pág. 34.

(25) Ibidem, págs. 34-35.

(26) Ibidem. 
segando á sus naturales por horrores espantosos, y la Europa toda reconoce esta adquisición por legítima (27).

Juan Bautista olvida, y, sobre todo, olvida que olvida. El suyo fue un pueblo belicoso que se extendió al precio de los horrores propios de todo imperio y de toda conquista. Por eso, el principal referente de las guerras de independencia en las Memorias no son las guerras indígenas, como lo será para una parte de la historiografía oficial peruana que paradójicamente se apoya en él, sino modelos extranjeros, particularmene criollos y europeos. Los ejemplos admirados por Juan Bautista son Francia, Argentina y los Estados Unidos (28), pasando por alto que en 1822, al redactar las Memorias, la expansión de este último país se realizaba, como en casi todo el continente, contra los indios. Este influjo europeo en Juan Bautista es confirmado al recordar la significación que para él tuvieron, siendo todavía prisionero, los grandes cambios políticos del Viejo Mundo:

A este movimiento de la naturaleza [la Revolución Francesa y las guerras napoleónicas] debo una libertad que jamás hubiera adquirido de otra manera (29).

no podía dejar hacer interiormente comparaciones del estado en que dejé el Cuzco y demás países con el que se me pintaba, y ciertamente sin el extremecimiento que ha producido en Europa la Revolución de Francia y la sentella de luz que ha arrojado por todas partes donde existía el combustible de la razón humana (30).

Parecería, a primera vista, que Juan Bautista se desdice en cada una de las líneas que escribe, y que nada en ellas desvela la realidad de la historia y del modo como América ha sido pensada por los americanos. Sin embargo, hay en las Memorias un potencial explicativo, que no proviene tanto de lo que afirman, sino de lo que ocultan, no de lo que se recuerda, sino de lo que se olvida.

(27) Ibidem, pág. 6.

(28) Ibidèm, pág. 7.

(29) Ibidem, pág. 2.

(30) Ibidem, pág. 29. 


\section{LA PARADÓJICA VERDAD DE LAS MEMORIAS}

Tal vez nunca haya estado Juan Bautista tan cerca de la realidad como al afirmar que los españoles destruyeron la ciencia inca, pues la mejor prueba de ello es que el $45^{\circ}$ nieto del último emperador del Perú» sólo puede demostrar un conocimiento somero de las tradiciones del pueblo al que quiere representar y cuyas raíces reivindica. Desde ese punto de vista, quizás una de la garantías de la autenticidad del escrito provenga de la escasa información que Juan Bautista puede proporcionar de la historia, de las tradiciones, de la religión, de la sociedad y, en general, de la forma de vida incaica. Si, en cambio, Juan Bautista pudiera instruirnos o darnos datos sobre su pueblo más allá de lo que lo hacen otros documentos, sobre todo españoles, las Memorias desmentirían lo que con tanto ahínco quieren probar: la destrucción sistemática de la familia más característica de su nación. Sin embargo, la coherencia de las Memorias queda a salvo, incluso en su desorden, al callar voluntaria o involuntariamente aquellas referencias que, en un texto testimonial, el semiólogo y el historiador debieran exigir. ¡Extraña suerte la de un escrito que debe su triunfo al fracaso de su proyecto semántico, que es el de mostrar a un hombre "como una víctima del despotismo que ha sobrevivido á sus golpes»! (31). No, Juan Bautista no logra su propósito en tanto cronista de un dolor ejemplar, y ello no se debe a la ausencia de datos por él aportados. No, Juan Bautista no logra probar la superioridad de la organización comunitaria indígena a la colonial (32). No, Juan Bautista no ha sobrevivido a los golpes, como no sobrevivió su pueblo. Lo que subsiste es sólo la carne y la sangre, mientras que el espíritu se ha quedado atrás, adormecido o muerto, no conservando de él, Juan Bautista, más que un reflejo pálido, más que un espejismo que por cierto brilla, pero con colores que no son los que el inca cree todavía ver.

Las Memorias interpretan las luchas independentistas dentro de una historia que es la historia de la razón y de la naturaleza humana por liberarse de la oscuridad y del despotismo. Ahora bien, la metafísica que interpreta la historia como la obra de la razón, o de la naturaleza humana, es una metafísica eurocentrista. Su forma de periodización tiene como punto de partida episte-

(31) Ibidem, pág. 1.

(32) Ibidem, pág. 34. 
mológico y temporal a Cristo, en cuyo nombre se realiza la colonización que Juan Bautista denuncia, o bien la superioridad de la razón encarnada en la técnica, fundamento moderno de la marginalidad indígena en las repúblicas americanas. En los dos casos se trata de un tiempo lineal y mesiánico, donde la sucesión es vista como progreso. Este pensamiento despoja a los incas del derecho que Juan Bautista reclama. Por este motivo, y a pesar de ciertas tradiciones nacionales y de ciertas tradiciones indigenistas, nada sería tan injusto y tan europeizante como buscar en las Memorias lo que se ha llamado una visión indigenista de la colonización y, menos aún, lo que la historiografía llama «la visión de los vencidos».

\section{5. ¿QUÉ SE ENTIENDE POR VISIÓN DE LOS VENCIDOS?}

La historiografía tradicional ha creído que basta con incluir o, por el contrario, con callar la destrucción de los pueblos indígenas para tomar partido por uno $u$ otro bando. El error de esta escuela, en la cual, voluntaria o involuntariamente, se sitúan muchos americanistas, consiste en pretender que la "visión de los vencidos" depende de los hechos narrados y del contenido material que la historiografía constata, más que del fundamento epistemológico del discurso que los describe. En realidad, no es sólo ni principalmente el hecho de narrar desgracias lo que constituye una visión de los vencidos, sino la perspectiva a partir de la cual se describe o piensa tanto los males como los bienes. En realidad, tanto la leyenda negra como la rosa quedan atrapadas en el marco de la epistemología y del metafísico occidental, por mucho que la primera la rechace verbalmente mientras que, la segunda, la asuma sin remordimientos. Buen ejemplo de este modo de pensar es Juan Bautista y los comentarios que ha merecido su vida y escritos. Juan Bautista, con todos los males que consigna, confirmados hoy por documentos que él mismo ignoraba, no logra constituir una visión propia de los vencidos. Su epistemología es la del vencedor, concretamente la de un humanista ecléctico cuyo discurso probablemente hubiera sido bien visto en las Cortes de Cádiz. El inca, al que podríamos incluir dentro de los autores adscritos a la llamada leyenda negra, permanece en el marco del eurocentrismo, tanto como pueda hacerlo Menéndez Pidal, cuyas tesis sobre el rol de España en América son opuestas. Juan Bautista declara a España res- 
ponsable de sus males en nombre de la universalidad de los derechos humanos, que es uno de los aspectos de la universalidad de la razón occidental. Esta universalidad es contradictoria con muchas prácticas de derecho consuetudinario nativo, que Juan Bautista pretende defender reclamando la soberanía inca en el Perú.

En respuesta a la historiografía tradicional, el concepto de "visión de los vencidos" fue acuñado por el historiador Miguel León-Portilla, quien titulara así ciertas crónicas indígenas que describen el desembarco de Cortés en México (33). Desgraciadamente, como la mayoría de los mejores americanistas, LeónPortilla, editor de las Crónicas Indígenas, pasa por alto, al menos en la Introducción a la edición española, el problema epistemológico y metodológico inaugurado por su propio trabajo, que debe fundar y criticar la recopilación de textos hecha por él. Refiriéndose al valor de los textos por él presentados, sostiene únicamente que las fuentes mexicanas constituyen uun cuadro indígena de la Conquista: una visión de los vencidos", conceptos que LeónPortilla no define.

La perspectiva epistemológica de algunas de dichas crónicas es radicalmente distinta de la de Juan Bautista. Al narrar la ocupación española, algunos textos mexicanos transmiten algo más que desazón y derrota. En efecto, a diferencia de las Memorias del inca, varias de las Crónicas presentan, además de la narración histórica, un modo de pensar la Conquista que la incorpora a la estructura y sistema indígenas de interpretación del mundo. En concreto, ciertas narraciones introducen la ocupación en la temporalidad cíclica de la mitología mexicana, en la que la llegada de los españoles es vista más como el retorno anunciado de los dioses que como un signo de novedad. La llegada de dioses extranjeros estaba prevista en las tradiciones y, el carácter nefasto del ciclo temporal en que arriba Cortés, en el calendario cósmico mexicano, confirmado por los presagios aparecidos poco tiempo antes del desembarco. Estos presagios son comparables a las profecías del Antiguo Testamento, aunque de signo negativo. Las profecías bíblicas preceden al mesías para que sea fácilmente reconocido, integrándolo, a pesar de su carácter excepcional, a la comunidad de creencias donde nace. Los presagios insertan las carabelas colombinas en la historia azteca, en cuya comunidad religiosa y metafísica las inscriben. La Con-

(33) Miguel León-Portilla (editor), Crónicas Indigenas: Visión de los Vencidos, Madrid, 1985. 
quista es vista así como el cumplimiento de un orden religioso preestablecido, orden hermenéutico que es exclusivamente mexicano. La historia providencial católica, fundamentalmente mesiánica y lineal, es fagocitada en la mente indígena por una historia cósmica y cíclica: xiuhcóatl, la serpiente de fuego, envuelve a la serpiente del Génesis antes de morir ahogada por los anillos de ésta.

La idea de visión de los vencidos puede ligarse a las tradiciones historicistas y fenomenológicas que buscan superar la perspectiva unilateral de quienes pretenden conocer los hechos pasados con independencia del punto de vista y la situación del testigo o del científico. Ni el historicismo ni la fenomenología negarían la unidad del objeto de estudio. Sin embargo, a la verdad absoluta de la historiografía clásica, el historicismo y la fenomenología oponen la multiplicidad de puntos de vista bajo los cuales éste puede ser analizado. Una y otra hacen entrar al testigo como una condición epistemológica de la verdad que corresponde a un hecho. El punto de vista deja así de ser un accesorio del cual el historiador debe deshacerse para conocer los acontecimientos pasados y se convierte en parte de la verdad. Como los puntos de vista son necesariamente múltiples y variables de una época a otra, la verdad correspondiente a un hecho cualquiera, por ejemplo la Conquista de América, es múltiple y distinta para cada uno de los pueblos involucrados, variando, además, a lo largo del tiempo. Ni para el historicismo ni para la fenomenología el historiador podría poseer la totalidad de los puntos de vista mientras la humanidad siga existiendo, pues es imposible de preveer las formas en que evolucionará y las perspectivas a que esta evolución dará lugar. Por eso, sólo se puede obtener una visión de conjunto recurriendo a la llamada «variación imaginaria», que completa los puntos de vista futuros o no accesibles en el presente gracias a la imaginación rigurosa y metódica de ellos.

El perspectivismo representa un progreso enorme frente a las visiones providencialistas y frente a la estéril e ingenua oposición entre las leyendas negra y rosa. Sin embargo, para esta doctrina todos los puntos de vista son a priori igualmente legítimos y ninguno excluye por principio a los demás. Planteamiento humanista por excelencia, supone la aceptación por todas las partes involucradas de una suerte de fair play epistemológico y del sometimiento de todos al tribunal imparcial de la razón. Esta, que por cierto es la razón occidental, pronuncia, no sentencias, 
sino verdades que han de entenderse como síntesis de pruebas materiales diversas. Aisladamente, cada una de ellas es falsa, pero en conjunto reconstituyen los hechos tal cual se supone que fueron. Por eso, tal forma de comprender la historia no permite elaborar la hipótesis de una visión de los vencidos en el sentido fuerte del concepto, es decir, en el sentido de un sistema hermenéutico indígena que fagocite el sistema interpretativo occidental.

El concepto de visión de los vencidos posee entonces una doble vertiente, que da lugar a dos tipos de narraciones: La primera vertiente consiste en textos, generalmente de origen indígena, que describen hechos dentro del campo de lo que para la historiografía eurocentrista puede ser real. Se trata de documentos nativos que pueden ser desmentidos o confirmados por la ciencia occidental, pues, aunque pongan en tela de juicio alguna de las pruebas aceptadas por las ciencias históricas, no discuten el conjunto de sistema argumentativo y probatorio de éstas, y, en particular, no discuten la metafísica y el sistema de valores morales sin los cuales dicha ciencia jamás hubiera existido. Susceptibles de ser consideradas como testimonio de las "víctimas», son entonces pruebas documentales de singular importancia y el complemento necesario de las visiones eurocentristas. Proporciona, además, una falsa confirmación de imparcialidad y de neutralidad, pues, bajo su pretensión de universalidad y no dejar a nadie de lado, impone como norma científica y como norma de análisis el humanismo liberal. Buen ejemplo de este tipo de narración son las Memorias de Juan Bautista Tupac Amaru, la substitución del concepto de Descubrimiento por el de Encuentro de Dos Mundos y algunas, sólo algunas, de las Crónicas Indígenas.

La segunda vertiente de la visión de los vencidos da lugar al sentido propio y fuerte del concepto. Consiste, no en una visión más que complemente o desmienta las europeas, sino en un sistema epistemológico y axiológico total, es decir, un sistema de conocimiento que, voluntaria o involuntariamente, es incompatible con otros sistemas de conocimiento. Esta incompatibilidad puede tener dos orígenes: o bien porque el sistema indígena se presenta como un sistema totalizante y excluyente, o bien porque el europeo rechaza que otros sistemas de conocimiento y otros sistemas de valores sean compatibles con el suyo. En sentido estricto, no es una visión, pues no complementa, sino que pone en tela de juicio los fundamentos y metodología de toda ciencia constituida 
sobre otras bases. Caben, bajo la rúbrica visión de los vencidos, en el sentido fuerte que acabamos de definir, algunas de las Crónicas, sobre todo los llamados presagios funestos. En cambio, las Memorias de Juan Bautista y el concepto de Encuentro de Dos Mundos quedan fuera de esta segunda y principal vertiente del concepto.

\section{SANGRE Y ESPÍRITU DE LA COMPRENSIÓN DE AMÉRICA}

Cualquiera que sea la hipótesis y la perspectiva que se adopte, urge constituir una ciencia cuyo objeto sea el estudio sistemático de los fundamentos, estructura, desarrollo, relaciones y supuestos involucrados tanto en la visión de los vencidos como en todo sistema hermenéutico cuyo objeto sea América. La necesidad de esta ciencia había sido prevista por León-Portilla, quien, aunque no la desarrolle, sugiere que:

además del asunto propiamente histórico de comparar los testimonios indígenas con los de los españoles, es posible contraponer las ideas propias de ese mundo indígena casi mágico, que tenía su raíz en los símbolos, con la mentalidad mucho más práctica y sagaz de quienes, superiores en la técnica, se interesaban principalmente por el oro (34).

Una ciencia de tal tipo, que en otro texto hemos llamado americología, no pretende conocer los hechos, tarea que deja a los historiadores, sino su representación (35). La americología, que es, no un modo de representar el continente americano, sino un modo de representar sus representaciones, pone de manifiesto los supuestos que éstas ocultan. Para la americología no hay privilegio alguno de las imágenes que se pretenden ficticias sobre la que se pretenden reales, pues estudia, justamente, los criterios con que las distintas culturas constituyen el campo de objetos posibles llamado "realidad" o "ficción americana». Por tanto, no le corresponde a ella distinguir lo verdadero de lo falso, decisión igualmente científica que moral, y no opone hechos a otros hechos, sino imágenes y palabras a palabras e imágenes. El modo como los hombres se representan la historia forma parte

(34) Ibìdem, pág. 36.

(35) Hernán Neira, "La idea de Origen en el Concepto de América" in Revista Arawcaria de Chile, nos, 47-48, Madrid. Ed. Michay, 1990. 
de la historia; lo que parece mitología a algunos parece ciencia a otros, a menos para quien se propone tratarlos sistemáticamente como discurso, como reconfiguración de los hechos, sin prejuzgar cuáles sean éstos ni sus características. La americología se sitúa, en consecuencia, en el campo de la semántica y de la epistemología, disciplinas que la historiografía sobre América ha ignorado tradicionalmente. Condición de su realización es tratar los distintos sistemas representativos en plano de perfecta igualdad, no sólo epistemológica, sino ética, sin suponer a ninguno de ellos superior, tarea que exige la puesta entre paréntesis de los valores morales de quien investiga. Por eso, la americología está vedada a quienquiera que le parezca imposible despojarse, como ejercicio metódico, de su sistema de valores, y a quienquiera que no esté dispuesto a practicar una suerte de moral provisional cartesiana durante el tiempo de su investigación.

En la tarea de comprender América, más importante que la sangre que corre por las venas de un autor es el espíritu que anima su investigación. La sangre se transmite de familia en familia y lentamente. El espíritu, en cambio, corre, se pierde y se mezcla rápido como un vértigo, sin que, a veces, ni siquiera el sujeto de las transformaciones mentales o culturales tenga tiempo de comprenderlas, sobre todo cuando su espíritu traspasa las fronteras de su propio continente intelectual para incorporarlo a las estructuras mentales de los pueblos que denuncia. Por eso, en la determinación de la perspectiva epistemológica asumida en las Memorias, resulta secundario el que hayan sido escritas por el puño y letra de Juan Bautista. Quienquiera que haya sido su autor material, es portavoz de una visión de mundo y de un sistema de interpretación que ha sido considerado testimonio esencial en la comprensión de América por la tradición peruana e indigenista. En las Memorias habla el espíritu de un pueblo que se reconoce ingenuamente en el espejo que Juan Bautista le tiende. Buscando reflejarse en él, cae en la trampa de un olvido que no se reconoce como tal. Nada sería entonces tan injusto como negar a Juan Bautista, retornando del destierro, la legítima y verídica participación en la comunidad cultural y nacional en que nació. Pero, paradójicamente, sería igualmente falso negar el vínculo que le une eclécticamente a una cultura europea.

Juan Bautista es la refutación del sincretismo, concepto con que se ha querido definir, en muchos casos, el resultado de la Conquista. Sincretismo existe, ciertamente, en algunos pueblos que pudieron o supieron conservar su memoria, pero no en los 
que sólo se encuentra un desgarro y un desarraigo totales. Tal es el caso de Juan Bautista y de la tradición que lo convierte en un representante de la cultura indígena: ¿cómo podría haber sincretismo cuando el espíritu nativo ha desaparecido en él? A menos, claro, que se cuestione algunos contenidos del concepto de indigenismo y se acepte que, quizás, el olvido, lejos de serle una característica accidental, contribuyen a formar su esencia. Eso equivale a aceptar el carácter histórico de la identidad indígena, la cual evoluciona adquiriendo nuevas fisonomías hasta el punto de que, lo que otrora le fuera propio, hoy pueda serle ajeno, y viceversa. Todo indica que para comprender a Juan Bautista haya que hacer uso de una representación evolutiva de lo indígena, es decir, que deba aceptarse como posible la transmutación completa, no de la sangre, sino del espíritu de los pueblos nativos.

Para Federico A. Loayza, Juan Bautista es «el símbolo del Sacrificio en la Vida y Pasión de los Pueblos Andinos» (36). Es verdad; sólo que la pertenencia a un pueblo, a su vida, a su pasión y tradiciones no se define sólo por la raza, el conocimiento o el haber vivido hechos verídicos junto a otros hombres, sino por la creencia en una misma mitología y en los proyectos que ella propone, así como por reconfigurar mentalmente los acontecimientos de un mismo modo. En las culturas donde la raza, definida exclusivamente por los rasgos físicos, no es el elemento fundamental para determinar la pertenencia al grupo, es sobre todo la visión de mundo, la forma de representar el pasado, el presente y el futuro que integran socialmente a los hombres. Si Juan Bautista merece la "devoción patriótica» (37) y a veces religiosa con que lo sacraliza Loayza (38), no se debe a que sea el portavoz de una memoria fiel reflejo de eventos nacionales, sino porque su dolor y su amnesia se identifican con el dolor y la amnesia colectivas, con el modo como la historia ha sido configurada en la inteligencia de sus compatriotas que, en mayor o menor grado, son interpelados por la forma en que Juan Bautista reconfigura por escrito su suerte. Juan Bautista Tupac Amaru es fiel representante de su pueblo, no porque hable en nombre de una raza o de una nación, sino porque su propio pueblo ha querido y quiere considerarlo su paladín. Ambos comparten una comunidad epistemológica y moral, una comunidad de espíritu y de proyectos. Ese mismo espíritu define, arbitraria pero coheren-

(36) Citado en: Inca Juan Bautista Tupac Amaru [8], pág. 21.

(37) Ibidem, pág. 76.

(38) Ibidem, pág. 21. 
temente, los fenómenos que pueden entrar en la historia y en el alma nacional, incluso antes de que tales fenómenos lleguen a producirse. Así, en la representación peruana de la historia, la representación que Juan Bautista tiene de ésta goza del rango, no de simple discurso, sino de espejo y testigo del pasado nacional.

Federico Loayza tiene razón, la tragedia de Tupac Amaru es la de los pueblos andinos, o al menos de los que otrora fueron los más poderosos y organizados. Sería injusto generalizar el caso de Juan Bautista y aplicarlo a decenas de comunidades que, protegidas por la selva o por el hecho de hallarse en zonas de escaso interés para conquistadores y criollos, han podido sobrevivir conservando su historia a través de un patrimonio intangible: tradiciones, formas de vida, lengua, esperanzas y, sobre todo, una forma propia de ver el mundo. En cuanto a otros pueblos, quizás la mayoría, la tragedia es más profunda de lo que Loayza cree y no consiste únicamente en dolores y destierros, sino en la dificultad inmensa de comprender el mundo y la destrucción de la que fueron víctimas. Tal vez allí resida la característica esencial del desarraigo de ciertos pueblos nativos. La desesperanza más total es la que, en demasía, ha sido privada de los medios para comprenderse, la de aquel que, en el momento de morir, no sabe por qué, para qué ni por quién muere. Juan Bautista, enfrentado al sucedáneo de la muerte que fue el destierro, se libra de la desesperanza (ojalá haya sido así) adquiriendo durante cuarenta años una nueva forma de comprender y de representarse el mundo en la que sus dolores tengan un sentido. La anti-memoria que cuajó en su cerebro tal vez le haya permitido sobrevivir y obtener una precaria salvación individual. Sin embargo, esta misma anti-memoria da lugar a que ciertas tradiciones, por concebir lo indígena como no susceptible de evolución, estén obligados a considerar las transformaciones de Juan Bautista como la muerte de un pueblo o de una cultura, tesis contraria a la nuestra.

Vana sería la esperanza de quien quisierá encontrar en las Memorias un punto de vista diferente del criollo o del europeo. Aunque paradójicamente utilizadas para proponer una visión indigenista de la historia peruana, una visión de los vencidos y en particular de su orgullo en la derrota, las Memorias no pueden ser consideradas más que como el testimonio de la defensa contra el del fiscal, pero sin llegar a cuestionar la legitimidad del juicio mismo en el que Europa inserta a América en lo que para 
el Viejo Mundo es la historia universal, es decir su historia universal.

Las Memorias, sin la claridad ni la precisión de los documentos oficiales, tiene el privilegio exclusivo de abrirnos el universo mental de Juan Bautista. Confuso y amargado, escribiendo o dictando en una lengua que no era la suya y que dominaba mal, cuenta sus males en el idioma que, más que desposeerle de su identidad, la modifica. Porque la identidad del inca no se fija en las luchas heroicas de 1780, ni en el momento de embarcarse para el destierro, ni en Ceuta, ni tampoco en el instante del regreso. Su caso, que tanto confunde a filósofos, historiadores y políticos, es el de los pueblos americanos, cuya identidad corre siempre más rápido que el discurso que intenta comprenderla.

Con todo, las Memorias proporcionan quizás una de las pocas representaciones de la historia que hayan llegado hasta hoy de manos, no de un cronista o sacerdote sino de quien perteneciera a una familia ilustre y de quien tomara parte, aunque sea secundaria, de la lucha y la derrota. ¿Son significativas de lo que existió, no en los campos de batalla andinos, sino en la mente de sus hermanos o inferiores partícipes en la rebelión? Nuestra hipótesis es afirmativa, aunque sólo un estudio de conjunto que tomase en cuenta documentos de uso privado, por ejemplo, la correspondencia de individuos comunes, podría esbozar una respuesta. Per habria, además, que evaluar el papel e intereses de cada grupo social. Tal vez entre los Tupac Amaru, familia prestigiosa y no exenta de recursos, y el resto del pueblo, la representación del rol del indígena en el gobierno y continente americano era profundamente distinta. Tal vez con tal estudio se pueda comprender una cierta distancia que separara el proyecto de los Tupac Amaru de muchos de sus hermanos de raza, que, junto a criollos y blancos, insultaban el cortejo del que formaba parte Juan Bautista camino al exilio:

las gentes se agolparon á las calles y balcones por donde debíamos pasar, y tal es la degradación, y estupidez de la servidumbre, que todos mostraban celebridad por un triunfo que había estrechado más sus cadenas y prolongado su esclavitud [la de "todos"]. Salimos más de 60 desgraciados [cuyo aspecto cadavérico...] lejos de mover la compasión, arrancaba por todas partes las palabras de pícaros traidores, que la paguen (subrayado en el original) (39).

(39) Ibidem, pág. 12. 
Otro hecho tendría lugar más tarde, aunque quizás más grave por provenir de un indígena también desterrado en Ceuta:

me fue mucho más insorportable la presencia de un indio que preguntándome, un día que me encontro en la calle, que si era cuzqueño, á la contestación de ser yo Tupamaro, lleno de furia me dijo que como me tenían todavía con vida, que hacía mucho debían haberme muerto (40).

Así, más allá de los eventos, tal vez el estudio de las Memorias y, en general, de las formas de representación, permita comprender por qué medios el colonizador ha transformado o transforma, en América, su dominio en obediencia, poniendo de relieve el papel nefasto de los grillos del espíritu que, por ser invisibles, son más difíciles de romper que los de hierro (41).

(40) Ibidem, pág. 27.

(41). Finalmente, el autor expresa su agradecimiento al Grupo de Sociología de la Literatura, de l'Ecole des Hautes Etudes en Sciences Sociales, París, que auspició esta investigación, así como a Marina Gergich y a Dorothea Heidecker quienes, desde Buenos Aires y Franckfurt respectivamente, hicieron posible la obtención de documentos sin los cuales este trabajo nunca hubiera podido concluir. 